\title{
Assessment of Alternative Protocols for Enumeration of Lactic Acid Bacteria Added As Starter Cultures in Salami Production
}

\author{
Natália Parma Augusto Castilho (I), Vivian T. Okamura (I), Fábio \\ Alessandro Pieri (I,II), Luís Augusto Nero (I) \\ (I) UFV - Universidade Federal de Viçosa (Campus UFV, Viçosa, MG, Brazil), (II) UFJF - \\ Universidade Federal de Juiz de Fora (Governador Valadares, MG, Brazil)
}

\section{Resumo}

The main starter cultures used for the production of fermented meat products are microorganisms from the group of lactic acid bacteria (LAB) and Staphylococcus coagulase negative. Monitoring the populations is essential for maintaining the quality and safety of these products. However, conventional methods for enumeration of starter cultures in foods have limitations, due to poor selectivity and handling. Considering the lack of scientific data demonstrating the relevance of using Petrifilm ${ }^{\mathrm{TM}} \mathrm{AC}$ plates associated with selective culture media for LAB enumeration in fermented meat products, the present study aimed to assess alternative protocols for the enumeration of starter culture in salami. Fourteen reference strains and two mix of starter cultures were plated on six different protocols: 1) Petrifilm ${ }^{\mathrm{TM}}$ AC added to chlorophenol red incubated in aerobiosis and 2) in anaerobiosis 3) agar MRS added to chlorophenol red 4) MRS added to bromocresol purple 5) MRS pH 5.7 and 6) agar All Purpose Tween. Then, samples of salami were obtained and their starter cultures enumerated by plating using protocols 1, 2, 3 and 5. The analysis of variance showed no significant differences between the enumeration protocols, independent of the incubation time: 24, 48 and $72 \mathrm{~h}$. Generally, the counts of pure cultures of microorganisms and reference starter cultures showed no significant differences considering the different incubation times (except for AS 308 and S. xylosus in MRS at $\mathrm{pH}$ 5.7). The results indicated a significant

\footnotetext{
Referência:

Natália Parma Augusto Castilho, Vivian T. Okamura, Fábio Alessandro Pieri, Luís Augusto Nero. Assessment of Alternative Protocols for Enumeration of Lactic Acid Bacteria Added As Starter Cultures in Salami Production. In: Anais do $12^{\circ}$ Congresso Latinoamericano de Microbiologia e Higiene de Alimentos - MICROAL 2014 [= Blucher Food Science Proceedings, num.1, vol.1]. São Paulo: Editora Blucher, 2014. DOI 10.5151/foodsci-microal-251
} 
correlation between the protocols, indicating equivalence between the counts of reference cultures and starter cultures in aerobiosis and anaerobiosis $(\mathrm{p}<0,05)$. The linear regression parameters also indicate appropriate correlations between the counts obtained after 24,48 and $72 \mathrm{~h}$ of incubation, indicating a reliability of the results obtained in a shorter analysis time ( $24 \mathrm{~h}$ ). Considering the results obtained in the enumeration of starter cultures in salami, no significant differences were observed among the protocols considered, independent of time and incubation conditions, and all correlations were significant $(\mathrm{p}<0,05)$, indicating equivalence between the protocols independent the conditions (aerobiosis and anaerobiosis) and time (24, 48 and $72 \mathrm{~h}$ ) of incubation. After morphological and molecular identification of isolates obtained from samples of salami by the tested protocols, it was observed an adequate selectivity, which allowed the formation of colonies only by Lactobacillus, Pediococcus and Staphylococcus coagulase negative, typically considered as starter cultures for the salami production. These results confirm the feasibility of using aerobic conditions and reduced incubation period for enumeration of starter culture on samples of salami, representing advantages to be considered during the monitoring of these microorganisms.

Palavras-Chave: starter cultures, salami, monitoring Agência de Fomento: CNPq, CAPES, FAPEMIG 